\title{
Inducing Resistance in Heliconia psittacorum cv. Golden Torch to Naturally Occurring Leaf Diseases
}

\author{
D. H. S. Sardinha ${ }^{1,2}$, A. A. C. Rodrigues ${ }^{2}$, J. R. M. Campos Neto ${ }^{1}$, L. G. L. Melo ${ }^{3}$, L. J. M. G. Oliveira ${ }^{2}$, \\ F. A. S. Diniz ${ }^{2} \&$ D. S. Paz \\ ${ }^{1}$ Instituto Federal Ciência e Tecnologia do Maranhão, Caxias, Maranhão, Brazil \\ ${ }^{2}$ Universidade Estadual do Maranhão, São Luis, Maranhão, Brazil \\ ${ }^{3}$ Verde Planta Ltda, Brazil \\ Correspondence: D. H. S. Sardinha, Instituto Federal de Educação, Ciência e Tecnologia do Maranhão, \\ 65600-505, Caxias, Maranhão, Brazil. Tel: 559-8981-268-217. E-mail: diogosardinha@ifma.edu.br
}

Received: August 17, 2018

doi:10.5539/jas.v10n12p385
Accepted: September 29, $2018 \quad$ Online Published: November 15, 2018

URL: https://doi.org/10.5539/jas.v10n12p385

\begin{abstract}
One of the bottlenecks to heliconia production is leaf diseases, which have the main characteristic of forming necrotic spots, that can reduce photosynthesis, damage the heliconia bracts and make the flowers unsuitable for commercialisation. The objective of the present study was to identify inducers capable of inducing resistance in H. psittacorum cv. Golden Torch, assessing by enzymatic action the reduction in the severity of the fungus complex associated to the cultivation of this species and verifying the action of the severity in relation to the net photosynthesis rate of the plants. The inducers were applied to the plants using a back spray and during application the plots were protected to prevent the products from drifting. The concentrations applied were Agro-Mos ${ }^{\circledR}\left(10 \mathrm{ml} \mathrm{L}^{-1}\right)$, Bion ${ }^{\circledR}\left(0.5 \mathrm{~g} \mathrm{~L}^{-1}\right)$, Quartz $\mathbb{}\left(40 \mathrm{ml} \mathrm{L}^{-1}\right)$, potassium phosphite $\left(3 \mathrm{~g} \mathrm{~L}^{-1}\right)$ and calcium phosphite $\left(3 \mathrm{~g} \mathrm{~L}^{-1}\right)$. During the experimental cultivation, the severity caused by the fungus complex and the photosynthetic rate of the plants were assessed and plant material was collected to analyse the enzymatic activity. The results indicated that the inducers Bion ${ }^{\circledR}$ and the phosphites applied reduced the fungus complex severity, increased the activity of peroxidase, polifenoloxidase and $\beta-1.3$ gluconase but did not cause alterations in the net photosynthesis rate of the plants. The value found for $\beta>1$ suggested that the visual estimation of the fungus complex severity is a good visual indicator of the effect of the plant pathogens on the host photosynthetic rate. The results are concrete responses to producers in the sector on management alternatives for diseases associated to heliconia cultivation.
\end{abstract}

Keywords: tropical flowers, disease management, enzymatic action, photosynthetic rate

\section{Introduction}

Heliconia are tropical herbaceous plants, belonging to the family Heliconiaceae. They are popularly known and appreciated because the blossoms have a wide range of colours and shapes (Taniguchi, Castro, T. F. Silva, E. B. da Silva, \& Martins, 2016). One of the bottlenecks to heliconia production is the occurrence of leaf diseases, which have the main characteristic of forming dark necrotic spots but can also damage the heliconia bracts and prevent their commercialisation. The leaf spots can also reduce photosynthesis because, according to Xavier et al. (2015), the main visual effect of leaf spot causing pathogens is reduced healthy, photosynthesising leaf area.

In the state of Maranhão, Brazil, diagnosis by Sardinha et al. (2012) indicated the occurrence of a fungus complex, causer of leaf spots, associated to species of Heliconia, including the fungal diseases caused by Curvularia eragrostides (Henn.), Curvularia lunata (Wakker) Boediin, Pestalotiopsis sp. and Colletotrichum gloeosporioides (Penz) frequently found in species of the family Heliconiaceae. Currently there is no single solution to control pests and diseases in floriculture and the best approach is based on integrating different management strategies, including chemical, crop, physical and biological control measures.

Management alternatives include the use of inducers that can induce plant resistance to plant pathogens. These inducers include Bion ${ }^{\circledR}$ or Acibenzolar-S-Methyl (ASM) that is a salicylic acid analog and acts on the plant metabolism inducing physiological and biochemical processes (Lima et al., 2017). Agro-Mos ${ }^{\circledR}$, constituted on the base of a phosphorylated mannanoligosaccaride from the cell wall of Saccharomyces cerevisiae Meyen, has 
been used to control post harvest diseases (Costa et al., 2010; Melo et al., 2016). Quartz ${ }^{\circledR}$ is a biological product based on Bacillus methylotrophicus, the genus Bacillus has been studied for plant nutritional quality, growth promotion and disease control (Harshavadhan, Kumar, Yathindra, Rajesh, \& Hongal, 2016; Moreira \& Araújo, 2013). Lastly the phosphites are a reduced form of phosphates and are suggested as biostimulators in horticulture that act on the plant metabolism (Gómez-Merino \& Trejo-Téllez, 2015). These products may influence the activity of some enzymes that are in directly associated to plant defence processes, including the enzymes $\beta$-1.3-glucanases, peroxidases and polyphenol oxidases.

In this context the objective of the present study was to identify inducers capable of inducing resistance in $H$. psittacorum cv. Golden Torch, assessed by enzymatic action and reduced severity of the fungus complex associated to the cultivation of this species, and to verify the action of the severity on the net photosynthesis rate of the plant.

\section{Material and Methods}

\subsection{Experimental Field}

The experiments were carried out at the Nucleus of Agronomic Biotechnology at the State University of Maranhão, Brazil $\left(2^{\circ} 30^{\prime} \mathrm{S}\right.$ and $\left.44^{\circ} 18^{\prime} \mathrm{W}\right)$, where H. psittacorum cv. Golden Torch plants were cultivated in soil classified as dystrophic sandy red yellow Argissolo (EMBRAPA, 2013), corrected to $\mathrm{pH} 6$ by applying limestone and fertilized monthly with cattle manure $\left(0.2 \mathrm{~kg} / \mathrm{m}^{2}\right)$. The cultivation was standardized by drastic pruning in all the area planted with $H$. psittacorum cv. Golden Torch and 30 days later the experiment was started by applying inducers to control the naturally occurring leaf plant pathogens associated to the culture. The inducer applications were repeated every 20 days, totaling five applications during the experiment. The inducers were applied using a back spray and during application the treatment plots were protected to prevent the products from drifting. The concentrations applied were: Agro-Mos ${ }^{\circledR}\left(10 \mathrm{ml} \mathrm{L}^{-1}\right)$, Bion ${ }^{\circledR}\left(0.5 \mathrm{~g} \mathrm{~L}^{-1}\right)$, Quartz ${ }^{\circledR}\left(40 \mathrm{ml} \mathrm{L}^{-1}\right)$, potassium phosphite $\left(3 \mathrm{~g} \mathrm{~L}^{-1}\right)$ and calcium phosphite $\left(3 \mathrm{~g} \mathrm{~L}^{-1}\right)$.

During the experiment, the severity of the leaf spots nd the net photosynthetic rate of the plants were assessed and plant material was collected to analyse the enzymatic activity.

\subsection{Identification of Naturally Occurring Plant Pathogens in the Experimental Area}

Leaves with disease symptoms were collected in the experimental area throughout assessment period. The collected material was isolated and identified according to Sardinha et al. (2012). Due to the similar symptomology of the various diseases associated to H. psittacorum cv. Golden Torch cultivation the term fungus complex was used for the group of plant pathogens identified in experimental area.

\subsection{Determining Leaf Spot Severity and Net Photosynthesis}

Leaf spot severity and net photosynthesis were assessed at 30,60 and 120 days after the start of the experiment. All treatments were compared to each other to demonstrate the results. To quantify the leaf spot, four leaves with similar physiological age were randomly collected with various infection levels. All the material was scanned and the lesions quantified using the software WinDias-Image Analysis System.

The gas exchanges of the H. pisitacorum cv. Golden Torch leaves were measured using the Li-6400 XT infrared gas analyser (LI-Cor, Lincoln, NE, USA), in response to irradiance of $2000 \mu \mathrm{mol}$ photons $\mathrm{m}^{-2} \mathrm{~s}^{-1}$ and $400 \mu \mathrm{mol}$ $\mathrm{mol}^{-1} \mathrm{CO}_{2}$. Measurements were only taken between 8 a.m. and 10:30 a.m. and on uniformly sunny days to minimize the sources of diurnal heterogeneity.

\subsection{Severity X Leaf Photosynthesis}

The relation between the fungus complex severity and the relative net photosynthetic rates (ratio between the net photosynthesis of diseased leaves and the mean net photosynthetic rate of healthy leaves, $\left.P_{x} / P_{o}\right)$ was determined by the model by Bastiaans (1991). The $\beta$ values were estimated by the equation $P_{x} / P_{o}=(1-x)^{\beta}$. The $T$ test was carried out to verify whether the $\beta$ values differed from the unit.

\subsection{Enzymatic Analyses}

Plant material for the enzymatic analysis was collected $0,24,48,96$ and 120 hours after applying the products, 50 days after the drastic pruning. Immediately after collection, the samples were frozen using liquid nitrogen, identified and kept in an ultrafreezer at $-80^{\circ} \mathrm{C}$ until the assessments.

\subsubsection{Obtaining the Extract for Enzyme Quantification}

The extraction was made according to the methodology adapted by Simões et al. (2015). Liquid nitrogen was used to homogenize $1 \mathrm{~g}$ fresh leaf tissue in $13 \mathrm{~mL}$ potassium phosphate buffer $0.2 \mathrm{~mol}(\mathrm{pH} \mathrm{6.0)}$ previously kept 
at $4{ }^{\circ} \mathrm{C}$. The extract was centrifuged at $13.000 \times g$ for 21 minutes at $4{ }^{\circ} \mathrm{C}$. The extract was stored in an ultrafreezer at $-80^{\circ} \mathrm{C}$ until the analyses were made.

\subsubsection{Peroxidase (POD, EC: 1.11.1.7) and Polyphenol Oxidase (PPO, EC: 1.10.3.1) Activity}

The POD trial was determined by adding $300 \mu \mathrm{L}$ of the supernatant to the reaction medium containing $1000 \mu \mathrm{L}$ phosphate buffer $0.2 \mathrm{~mol}(\mathrm{pH} 6.0), 100 \mu \mathrm{L}$ guaiacol $(0.5 \%)$ and $100 \mu \mathrm{L}$ hydrogen peroxide $(0.08 \%)$. The readings were made on a spectrophotometer at $470 \mathrm{~nm}$ and $25^{\circ} \mathrm{C}$, for three minutes. The peroxidase activity was calculated based on the molar extinction coefficient of $26.6 \mathrm{mM} \mathrm{cm}^{-1}$ for guaicol, and expressed in $\mu \mathrm{mol} \mathrm{g}^{-1}$ $\min ^{-1}$. (MF)

The PPO trial was determined by adding $50 \mu \mathrm{L}$ of the supernatant to reaction medium containing $1650 \mu \mathrm{L}$ phosphate buffer $0.2 \mathrm{~mol}(\mathrm{pH}$ 6.0) and $1300 \mu \mathrm{L}$ catechol $(0.2 \mathrm{~mol})$. The readings were made in a spectrophotometer at $425 \mathrm{~nm}$ and $25{ }^{\circ} \mathrm{C}$, for two minutes. The PPO activity was calculated based on the molecular extinction coefficient of $34 \mathrm{mmol} \mathrm{cm}^{-1}$ for catechol and expressed in $\mu \mathrm{mol} \mathrm{g}^{-1} \mathrm{~min}^{-1}$ (MF).

\subsection{3 $\beta$-1.3-Gluconase (EC: 3.2.1.39) Activity}

$\beta$-1.3-gluconase was determined by the dosage of glucose released with lamarine hydrolysis (Tuzun, Rao, Vogeli, Schardl, \& Kuc, n.d.). The following were transferred to two test tubes: $25 \mu \mathrm{L}$ enzymatic extract, $200 \mu \mathrm{L}$ potassium phosphate buffer $(0.2 \mathrm{~mol}$ and $\mathrm{pH} 6.0)$ and $200 \mu \mathrm{L}$ laminarine $\left(5 \mathrm{mg} \mathrm{mL}^{-1}\right)$. This material was incubated at $37^{\circ} \mathrm{C}$ for 30 minutes and then $1 \mathrm{~mL}$ Somogyi reagent (Smogyi, 1952) and $5 \mathrm{ml}$ deionised distilled water were added and shaken for 10 minutes. After shaking, the material was heated to $100{ }^{\circ} \mathrm{C}$ for 15 minutes and chilled in a ice bath. Then $1 \mathrm{~mL}$ Nelson reagent (Smogyi, 1952) and $15 \mathrm{ml}$ deionised distilled water were added and shaken for 15 minutes. The spectrophotometric readings at $760 \mathrm{~nm}$ of the samples were compared with glucose standards. The standard glucose curve was prepared by adding the standard, in the same way as the samples, substituting the laminarine with glucose solutions ranging from 0 to $800 \mathrm{mg} \mathrm{L}^{-1}$.

\subsection{Statistical Analysis}

The experimental field measured $22 \times 14$ meters and the experimental plots $2 \times 2 \mathrm{~m}$, totaling $4 \mathrm{~m}^{2}$ and $1 \mathrm{~m}^{2}$ central useful area per plot. A completely randomised design was used, placed in random blocks, with four replications. The data found for severity and relative net photosynthesis were correlated and submitted individually to analysis of variance in a factorial scheme ( 6 products $\times 3$ periods), while the enzymatic activity was also submitted to analysis of variance, but analyzed separately in each period. The means of the parameters, when significant, were compared by the Tukey test $(\mathrm{p}<0.05)$, using the software STATISTICA (Stat-Soft, Tulsa, EUA).

\section{Results}

\subsection{Identification of Naturally Occurring Plant Pathogens in the Experimental Area}

The following naturally occurring plant pathogens were identified in the experiment: Curvularia eragrostides (Henn.) J. A. Mey, Pestalotiopsis sp., Colletotrichum gloeosporioides (Penz), Curvularia lunata (Wakker) Boedijn and Alternaria sp. The plant pathogens cited formed the fungus complex associated with $\mathrm{H}$. psittacorum cv. Golden Torch cultivation, present in the lesions, that tended to coalesce causing complete drying of the leaves and served as inoculum source for the bract infection.

\subsection{Severity}

The statistical analysis was significant for the measured factors. Generally the fungus complex severity, associated with $H$. psittacorum cv. Golden Torch cultivation, increased during the three assessment periods. However, the fungus complex was shown to expand its colonisation differentially when plants treated with inducers were compared with the control treatment (Figure 1). 


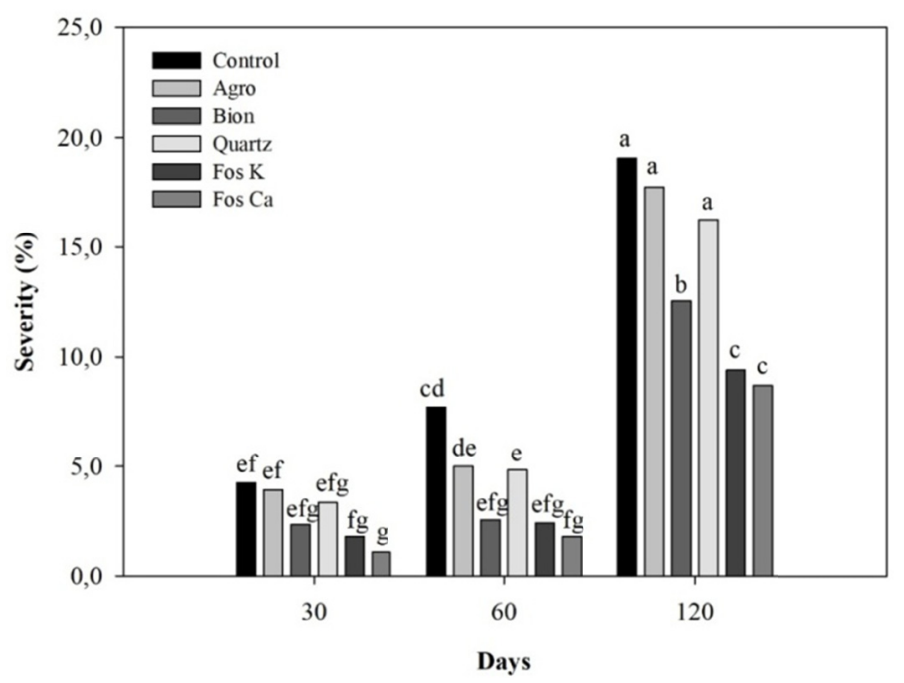

Figure 1. Severity of leaf diseases associated with Heliconia psittacorum cv. Golden Torch treated with Agro-Mos ${ }^{\circledR}\left(\right.$ Agro), Bion ${ }^{\circledR}$, Quartz ${ }^{\circledR}$, potassium phosphite (Fos K) and calcium phosphite (Fos Ca). The same letters indicate equality among the treatments by the Tukey test $(5 \%)$

Among the inducers used, calcium phosphite differed statistically from the control treatment throughout the assessment period. Starting at the second assessment, potassium phosphite and Bion ${ }^{\circledR}$ were also different from the control. Notably, the plants treated with calcium phosphite, potassium phosphite and Bion ${ }^{\circledR}$ presented reduced severity at the end of the assessments, compared to the other treatments.

\subsection{Leaf Photosynthesis}

The statistical analysis was significant only for the assessment period. Generally a decrease was observed in the photosynthetic rate, especially in the 60-120 day interval in the assessments. However, the inducers assessed did not cause significant alterations in the photosynthetic rate compared to the control (Figure 2).

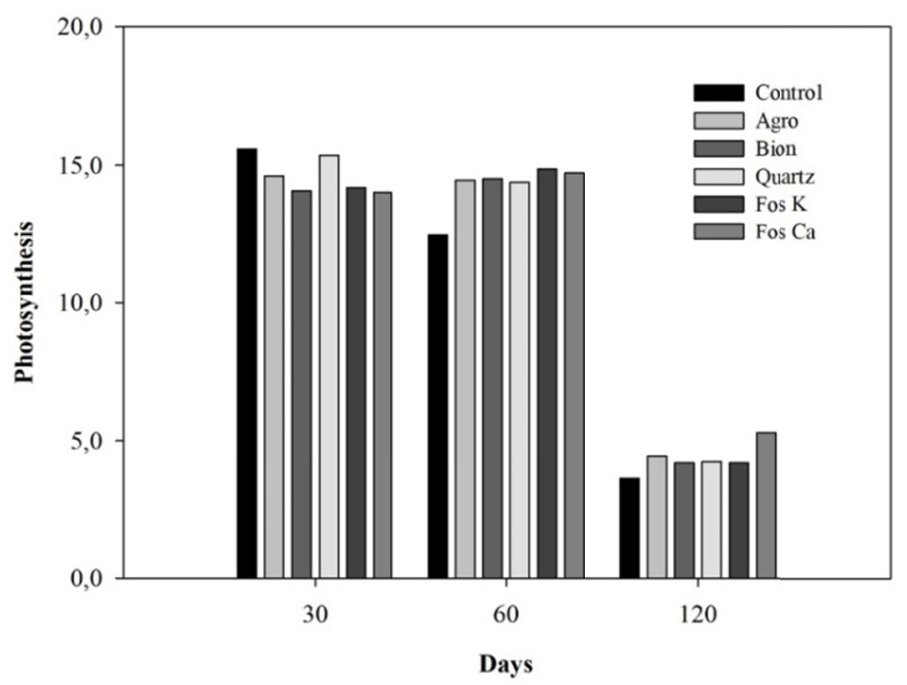

Figure 2. Photosynthesis measured in Heliconia psittacorum cv. Golden Torch plants treated with Agro-Mos ${ }^{\circledR}$ (Agro), Bion ${ }^{\circledR}$, Quartz ${ }^{\circledR}$, potassium phosphite (Fos K) and calcium phosphite (Fos Ca)

\subsection{Severity X Leaf Photosynthesis}

Photosynthesis and severity were strongly and negatively correlated $(r=-0.8527)$ and generally leaves with fungus lesions had a lower photosynthetic rate compared to healthy leaves (Figure 3). 


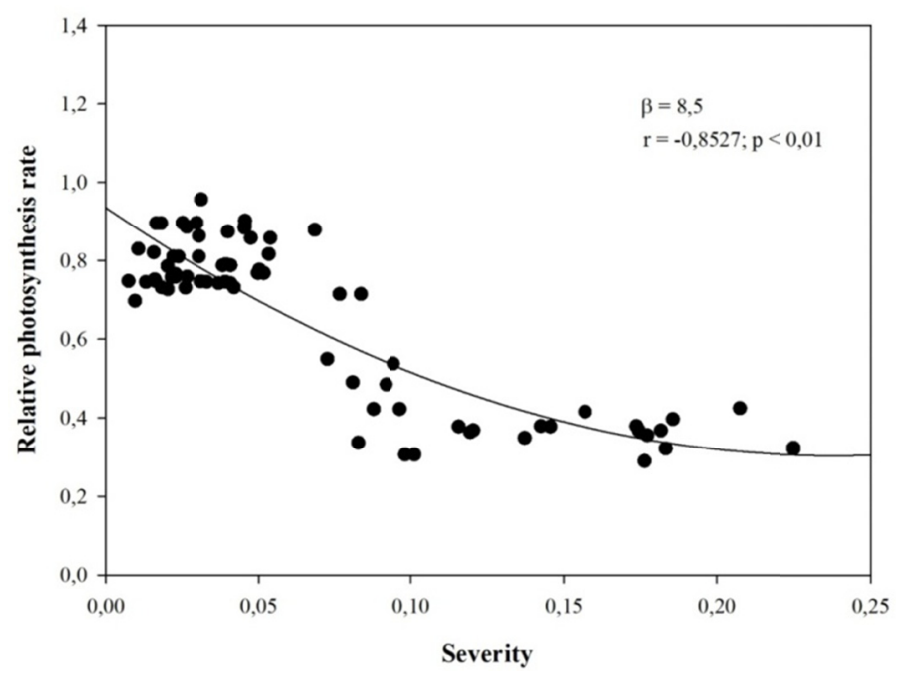

Figure 3. Relative net photosynthetic rate (Px/Po) of Heliconia psittacorum Golden Torch leaves infected naturally, in function of the magnitude of the fungus complex severity

The maximum severity observed in the H. psittacorum cv. Golden Torch leaves was $19.05 \%$, the mean value observed in the plants of the control treatment (Table 1).

Table 1. Observations, maximum severity, $\beta$ coefficients and confidence interval, for the fungus complex associated with Heliconia psittacorum cv. Golden Torch

\begin{tabular}{lllll}
\hline \multirow{2}{*}{ Observations } & \multirow{2}{*}{ Maximum severity (\%) } & \multirow{\beta}{*}{$\boldsymbol{\beta}$ Coefficients } & \multicolumn{2}{c}{ Confidence interval of the $\boldsymbol{\beta}$ coefficient } \\
\cline { 3 - 5 } & & & Inferior & Superior \\
\hline 72 & 19.05 & 8.5 & 5.93 & 11.06 \\
\hline
\end{tabular}

The estimated $\beta$ ( \pm standard error) parameter was $8.5( \pm 0.78)(\mathrm{p}<0.01)$ for leaves attacked by the fungus complex. The $\beta$ value obtained for the fungus complex associated to $H$. psittacorum cv. Golden Torch was statistically bigger than $1(\mathrm{p}<0.01)$.

\subsection{Peroxidase (POD, EC: 1.11.1.7) and Polyphenol Oxidase (PPO, EC: 1.10.3.1) Activity}

It was usually possible to characterize increase in enzymatic activity for the enzymes peroxidase (POD) and polyphenol oxidase (PPO) in inducer treated plants. The POD enzyme performance was characterised by increase in activity after 24 hours, when the potassium phosphite stood out, but the activity peak of this enzyme in plants treated with inducers occurred 48 hours after the applications, for most of the treatments, highlighting Bion ${ }^{\circledR}$, calcium phosphite and potassium phosphite, in this order, that presented bigger enzymatic activity, differing statistically from the control treatment and other inducers (Figure 4). The other inducers, Quartz ${ }^{\circledR}$ and Agro-Mos ${ }^{\circledR}$, presented POD activity peak 96 hours after application, and differed statistically from the control treatment, but were not different compared to Bion $®$, calcium phosphite and potassium phosphite. 


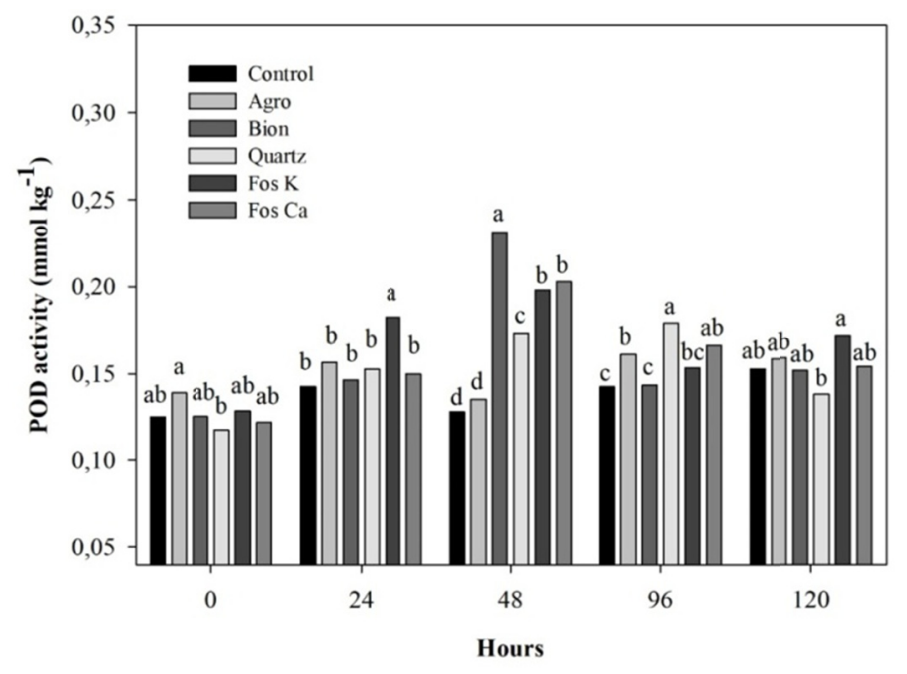

Figure 4. Peroxidase activity associated to Heliconia psittacorum cv. Golden Torch treated with Agro-Mos ${ }^{\circledR}$ (Agro), Bion ${ }^{\circledR}$, Quartz ${ }^{\circledR}$, potassium phosphite (Fos K) and calcium phosphite (Fos Ca)

The PPO enzyme presented pronounced activity peak 48 hours after applying inducers. Plants treated with calcium phosphite, Bion ${ }^{\circledR}$ and potassium phosphite, in this order, differed from the other treatments, including the control. The inducers Quartz ${ }^{\circledR}$ and Agro-Mos ${ }^{\circledR}$ presented PPO activity peak 24 hours after application and were different statistically from the control treatment, but did not differ compared to the other inducers, calcium phosphite, Bion ${ }^{\circledR}$ and potassium phosphite (Figure 5).

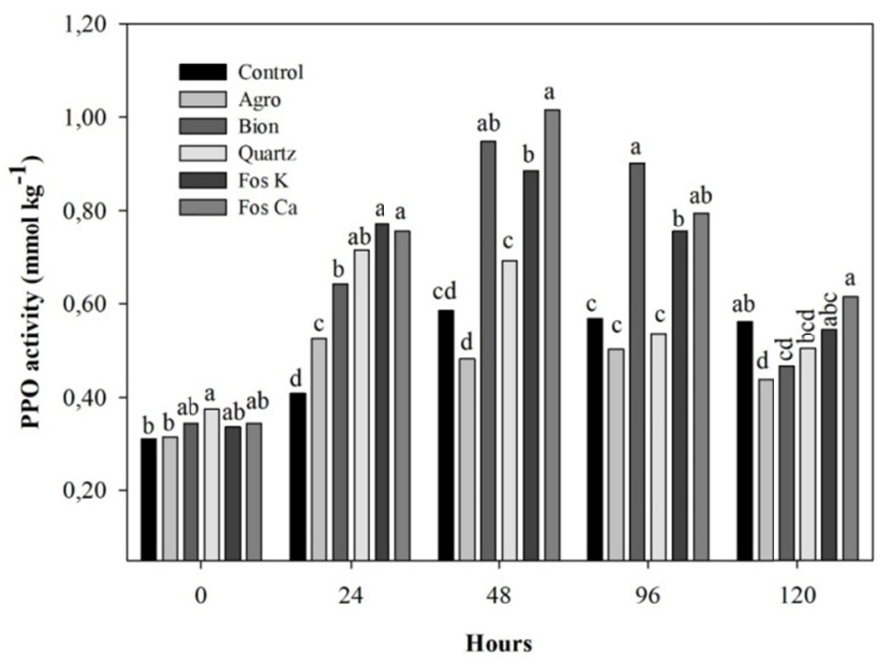

Figure 5. Polyphenol oxidase activity associated with Heliconia psittacorum cv. Golden Torch treated with Agro-Mos ${ }^{\circledR}$ (Agro), Bion ${ }^{\circledR}$, Quartz ${ }^{\circledR}$, potassium phosphite (Fos K) and calcium phosphite (Fos Ca)

\section{6 $\beta$-1.3-Glucanase Activity}

Generally, $\beta-1,3$-glucanase activity increased during the period assessed, but an activity peak could not be characterized for all the inducers tested. Only Bion ${ }^{\circledR}$ presented an activity peak statistically bigger than the control treatment and only 96 hours after application (Figure 6). 


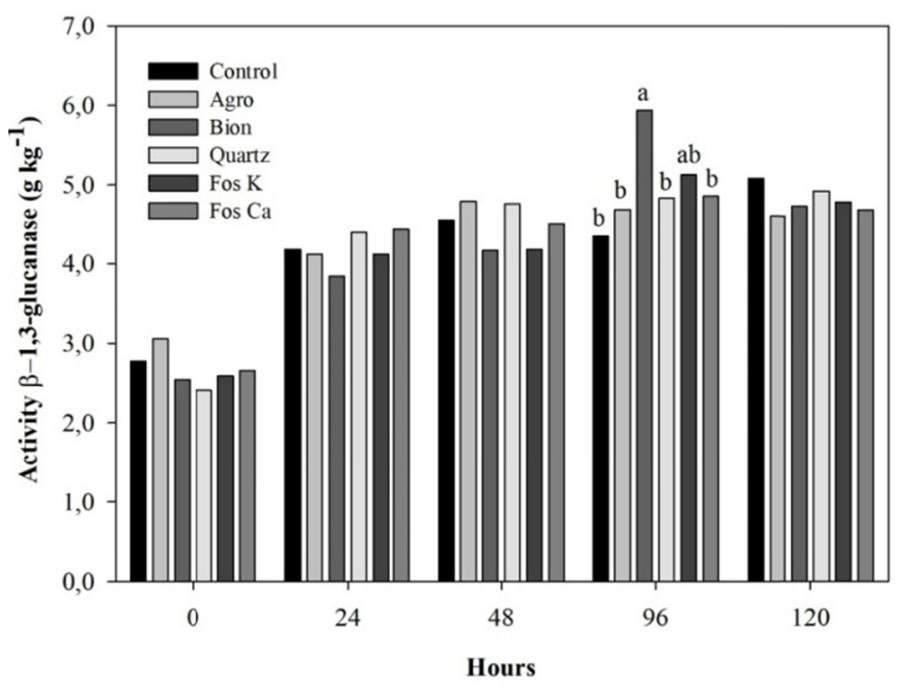

Figure 6. $\beta-1,3$-glucanase activity associated to Heliconia psittacorum cv. Golden Torch treated with Agro-Mos ${ }^{\circledR}$ (Agro), Bion ${ }^{\circledR}$, Quartz ${ }^{\circledR}$, potassium phosphite (Fos K) and calcium phosphite (Fos Ca)

\section{Discussion}

The naturally occurring plant pathogens identified during the experiment had already been reported in tropical flower cultivation on the island of São Luís, Brazil, as causal agents of leaf diseases in heliconia species (Sardinha et al., 2012) and can be considered a fungus complex causer of diseases in H. psittacorum cv. Golden Torch.

According to the results found, the inducers calcium phosphite, potassium phosphite and Bion ${ }^{\circledR}$ were able to reduce damage caused by the fungus complex, possibly ensuring better conditions for the plant to produce higher quality flowers. The reduction in severity resulting from the phosphites probably involved direct control of the fungus complex because the fungitoxic action of phosphite was studied previously in several pathogen systems over the years (Araújo, Valdebenito-Sanhueza, \& Stadnik, 2010; Dianese et al., 2008; Sobrinho et al., 2016; Spolti, Valdebenito-Sanhueza, Campos, \& Del Ponte, 2015), including the genus Colletotrichum (Oliveira, Pinto Viana, \& Valentim Martins, 2016) that is frequently found in the fungus complex associated to H. psittacorum cv. Golden Torch cultivation.

In addition to direct control, it can be suggested that the phosphites induced resistance in H. psittacorum cv. Golden Torch plants because peroxidase and polyphenol oxidase activity increased compared to the control treatment. The use of inducers and plant stress can cause increase peroxidase activity and consequently cell protection against oxidative reactions (Anterola \& Lewis, 2002). Increases in the percentages of peroxidase activity were also been detected in peachtree plants with early death symptoms, consequence of the situation of physiological stress caused by the disease (Marafon, Herter, Bacarin, \& Hawerroth, 2009), since the infectious action caused by the pathogen can result in hydrogen peroxide synthesis (Furstenberg-Hagg, Zagrobelny, \& Bak, 2013). Peroxidase and phenol oxidase are integrated in various physiological processes in the plant, such as lignification, suberization, cell wall component formation and reticulation and senescence (Nascimento \& Barrigossi, 2014).

According to Lobato et al. (2011) potassium phosphite leaf applications induced increase in peroxidase and polyphenol oxidase activity in potato tubers, and these alterations were part of the defence mechanism induced by phosphites. Ramezani et al. (2017) suggested that potassium phosphite prepared plants for a rapid, intense response to infection, involving the activation of various defence responses, including the expression of defence genes via the phenylpropanoid route.

The reduction in severity caused by Bion ${ }^{\circledR}$ was not associated to direct control because it showed no or low fungitoxic activity (Barros, Fonseca, Balbi-Peña, Pascholati, \& Peitl, 2015; Oliveira et al., 2016), but its rapid absorption by the plant stimulated resistance by interfering in physiological and biochemical processes (Debona et al., 2009). It is also frequently associated to the salicylic acid metabolic paths because it activates genes referent to resistance signalling (Vitti, 2009) and consequently the action of proteins relative to the pathogenesis (PRP`s) (Felipini \& Piero, 2013). In the present study, the enzymes assessed, peroxidase, polyphenol oxidase and 
$\beta-1,3$-gluconase, increased their activity and the plants treated with this inducer characterized the process of resistance induction.

The other inducers, Agro-Mos ${ }^{\circledR}$ and Quartz ${ }^{\circledR}$, although they acteds efficaciously in other pathogen systems as resistance inducers or even plant pathogen antagonists (Melo et al., 2016; Yánez-Mendizábal \& Falconí, 2018), did not reduce the severity of the fungus complex in H. psittacorum cv. Golden Torch cultivation.

None of the inducers assessed interfered directly in the net photosynthesis rate of $H$. psittacorum cv. Golden Torch, but the severity and net photosynthesis rate were strongly and negatively correlated, suggesting that fungus infection, if it is not controlled, may reduce net photosynthesis in the plant.

The $\beta$ value estimated at $8.5( \pm 0.78)$ indicated that the plants infected by the fungus complex had photosynthesis damage not only in the lesion area, but also in the apparently healthy region of the leaf. Consequently, the calculated severity is a good indicative of the effect of the fungus complex on photosynthesis in H. psittacorum cv. Golden Torch plants. Although the net photosynthetic rate measurements demonstrated that the fungus complex reduced photosynthesis in the remaining green tissue, these measurements did not elucidate the mechanism responsible for the reduction or indicate the localization of this effect. Johnson (1987) considered that pathogen presence in diseased tissue may influence the crop development by reducing the solar radiation interception (RI) by the green matter or by interference in the radiation use efficiency (RUE). This experiment demonstrated that the spots caused by the fungus complex is an example where both effects occur. References were not found for this parameter in this pathogen system. However, this effect has been observed in pathogen systems such as Phaeosphaeria maydis in corn (Godoy, Amorim, \& Bergamin Filho, 2001) and Corynespora cassiicola in soybean (Xavier et al., 2015).

These results suggested that when promoting reduction in the fungus complex severity associated to $H$. psittacorum cv. Golden Torch the phosphites, indirectly, permitted the plant to maintain its net photosynthesis rate close to that found in healthy plants, that would probably permit better quality flower production. These results have been confirmed in research already carried out by the authors (data in publication) when the effects were observed of the inducers, potassium phosphite and calcium phosphite, applied in the field, on the quality of H. psittacorum cv. Golden Torch flowers post harvest.

\section{Considerations}

The inducer Bion ${ }^{\circledR}$ and the phosphites applied in the field were efficacious in reducing the fungus complex severity associated to $H$. psittacorum $\mathrm{cv}$. Golden Torch

The net photosynthesis rate was not affected by the inducers assessed, but the fungus complex can reduce the photosynthesis rate as severity increases.

The value found for $\beta$ bigger than 1, suggests that the visual estimate of the fungus complex severity is a good in visual indicator of the effect of the plant pathogens on the photosynthetic rate of the host.

The results presented here contribute to the understanding of a little studied pathogen system and give concrete responses to tropical flower producers on management alternatives for the diseases associated to heliconia cultivation.

\section{Acknowledgements}

We thank the Foundation for Research Support and Scientific and Technological Development of the State of Maranhão (Fundação de Amparo à Pesquisa e Desenvolvimento Científico e Tecnológico do Estado do Maranhão (FAPEMA) for supporting this research.

\section{References}

Anterola, A. M., \& Lewis, N. G. (2002). Trends in lignin modification: A comprehensive analysis of the effects of genetic manipulations/mutations on lignification and vascular integrity. Phytochemistry, 61(3), 221-294. https://doi.org/10.1016/S0031-9422(02)00211-X

Araújo, L., Valdebenito-Sanhueza, R. M., \& Stadnik, M. J. (2010). Evaluation of potassium phosphite formulations against Colletotrichum gloeosporioides in vitro and for post-infection control of Glomerella leaf spot in apple. Tropical Plant Pathology, 35(1), 54-59. https://doi.org/http://dx.doi.org/10.1590/S198256762010000100010

Barros, D. C. M., Fonseca, I. C. de B., Balbi-Peña, M. I., Pascholati, S. F., \& Peitl, D. C. (2015). Biocontrol of Sclerotinia sclerotiorum and white mold of soybean using saprobic fungi from semi-arid areas of Northeastern Brazil. Summa Phytopathologica, 41(22), 251-255. https://doi.org/10.1590/0100-5405/2086 
Bastiaans, L. (1991). Ratio Between Virtual and Visual Lesion Size as a Measure to Describe Reduction in Leaf Photosynthesis of Rice Due to Leaf Blast. Phytopathology, 81(6), 611. https://doi.org/10.1094/Phyto-81-611

Costa, J. D. B., de Resende, M. L. V, Ribeiro, P. M., Camilo, F. R., Monteiro, A. C. A., \& Pereira, R. B. (2010). Induction of resistance in cacao seedlings against Moniliophthora perniciosa by a phosphorilated mannanoligosaccharide based product. Tropical Plant Pathology, 35(5), 285-294.

Debona, D., Figueiró, G. G., Corte, G. D., Navarini, L., Domingues, L. da S., \& Balardin, R. S. (2009). Effect of seed treatment with fungicides and acibenzolar-S-methyl in soybean cultivars on Asian rust control and seedlings growth. Summa Phytopathologica, 35(1), 26-31. https://doi.org/10.1590/S0100-540520090001 00004

Dianese, A. D. C., Blum, L. E. B., Dutra, J. B., Lopes, L. F., Sena, M. C., \& De Freitas, L. F. (2008). Evaluation of phosphite applications for severity of papaya black spot (Asperisporium caricae). Revista Brasileira De Fruticultura, 30(3), 834-837. https://doi.org/10.1590/S0100-29452008000300047

EMBRAPA. (2013). In H. G. dos Santos, P. K. T. Jacomine, L. H. C. dos Anjos, V. Á. de Oliveira, J. F. Lumbreras, M. R. Coelho, ... J. B. de Oliveira (Eds.), Sistema Brasileiro de Classificação de Solos (3rd ed.). Brasilia: EMBRAPA. Retrieved from http://livimagens.sct.embrapa.br/amostras/00053080.pdf

Felipini, R., \& Piero, R. Di. (2013). PR-protein activities in table beet against Cercospora beticola after spraying chitosan or acibenzolar-S-methyl. Tropical Plant Pathology, 38(December), 534-538. https://doi.org/ 10.1590/S1982-56762013000600009

Furstenberg-Hagg, J., Zagrobelny, M., \& Bak, S. (2013). Plant Defense against Insect Herbivores. International Journal of Molecular Sciences, 14(5), 10242-10297. https://doi.org/10.3390/ijms140510242

Godoy, C. V., Amorim, L., \& Bergamin Filho, A. (2001). Changes in photosynthesis and transpiration of corn leaves infected by Phaeosphaeria maydis. Fitopatologia Brasileira, 26(2), 209-215. https://oi.org/10.1590/ S0100-41582001000200017

Gómez-Merino, F. C., \& Trejo-Téllez, L. I. (2015). Biostimulant activity of phosphite in horticulture. Scientia Horticulturae. https://doi.org/10.1016/j.scienta.2015.09.035

Harshavadhan, M., Kumar, D. P., Yathindra, H. A., Rajesh, A. M., \& Hongal, S. (2016). Effect of integrated nutrient management on soil health, nutrient uptake, flower quality and yield of carnation (Dianthus caryophyllus L.). Environment \& Ecology, 34, 1862-1867.

Johnson, K. B. (1987). Defoliation, Disease, and Growth: A Reply. The American Phytopathological Society, 77(11), 1495-1497.

Lima, M. A. G., Peixoto, A. R., Borges, I. V., Silva, M. S., Barbosa, M. A. G., \& Cavalcanti, L. S. (2017). Induction of Resistance to Xanthomonas campestris pv. Viticola in Grapevine Plants. Sociedade Brasileira de Fruticultura, 39(4). https://doi.org/10.1590/0100-29452017669

Lobato, M. C., Machinandiarena, M. F., Tambascio, C., Dosio, G. A. A., Caldiz, D. O., Daleo, G. R., ... Olivieri, F. P. (2011). Effect of foliar applications of phosphite on post-harvest potato tubers. European Journal of Plant Pathology, 130(2), 155-163. https://doi.org/10.1007/s10658-011-9741-2

Marafon, A. C., Herter, F. G., Bacarin, M. A., \& Hawerroth, F. J. (2009). Atividade da peroxidase durante o período hibernal de plantas de pessegueiro (Prunus persica (L.) Batsch.) cv. jubileu com e sem sintomas da morte precoce. Revista Brasileira de Fruticultura, 31(4), 938-942. https://doi.org/10.1590/S0100-2945200 9000400004

Melo, L. G. de L., Silva, E. K. C. e, Campos Neto, J. R. M., Lins, S. R. de O., Rodrigues, A. A. C., \& Oliveira, S. M. A. de. (2016). Abiotic resistance inducers for control of pineapple fusariosis. Pesquisa Agropecuária Brasileira, 51(10), 1703-1709. https://doi.org/10.1590/s0100-204x2016001000001

Moreira, A. L. de L., \& Araújo, F. F. de. (2013). Bioprospectionof Bacillus spp. as potential growth promoters in Eucalyptus urograndis. Revista Árvore, 37(5), 933-943. https://doi.org/10.1590/S0100-67622013000500016

Nascimento, J. B., \& Barrigossi, J. A. F. (2014). The Role of Antioxidant Enzymes in Plant Defense Against Herbivorous Insects and Phytopathogens. Agrarian Academy, 1(1), 235.

Oliveira, E. de, Pinto Viana, F. M., \& Valentim Martins, M. (2016). Alternatives to fungicides in the control of banana anthracnose. Summa Phytopathologica, 42(4), 340-350. https://doi.org/10.1590/0100-5405/2000

Ramezani, M., Rahmani, F., \& Dehestani, A. (2017). The effect of potassium phosphite on PR genes expression 
and the phenylpropanoid pathway in cucumber (Cucumis sativus) plants inoculated with Pseudoperonospora cubensis. Scientia Horticulturae, 225, 366-372. https://doi.org/10.1016/j.scienta.2017. 07.022

Sardinha, D. H. S., Rodrigues, A. A. C., Diniz, N. B., Lemos, R. N. S. de, \& Silva, G. S. da. (2012). Fungi and phytopathogenic nematodes associated with tropical flower cultivation in São Luís, Maranhão State, Brazil. Summa Phytopathologica, 38(2), 159-162. https://doi.org/10.1590/S0100-54052012000200010

Simões, A. D. N., Moreira, S. I., Mosquim, P. R., Soares, N. D. F. F., \& Puschmann, R. (2015). The effects of storage temperature on the quality and phenolic metabolism of whole and minimally processed kale leaves. Acta Scientiarum. Agronomy, 37(1), 101. https://doi.org/10.4025/actasciagron.v37i1.18123

Smogyi, M. (1952). Notes on sugar determination. J Biol Chem, 195(1), 19-23.

Sobrinho, G. G. R., Rodrigues, G. B., Santos, A., Jesus Junior, W. C. de, Novaes, Q., \& De, S. (2016). Effect of potassium phosphite on the mycelial growth and density of Fusarium solani in passion flower vine. Summa Phytopathologica, 42(2), 180-182. https://doi.org/http://dx.doi.org/10.1590/0100-5405/2139

Spolti, P., Valdebenito-Sanhueza, R. M., Campos, Â. D., \& Del Ponte, E. M. (2015). Modo de ação de fosfitos de potássio no controle da podridão olho de boi em maçã. Summa Phytopathologica, (9), 42-48. https://doi.org/ $10.1590 / 0100-5405 / 1982$

Taniguchi, C. A. K., Castro, A. C. R. de, Silva, T. F., Silva, E. B. da, \& Martins, T. da S. (2016). Growth, nutrient accumulation and export by heliconia 'Red Opal.' Ornamental Horticulture, 22(3). https://doi.org/10.14295/ oh.v22i3.954

Tuzun, S., Rao, M. N., Vogeli, U., Schardl, C. L., \& Kuc, J. (n.d.). Induced systemic resistance to blue mold: Early induction and accumulation of beta-1,3-glucanases, chitinases, and other pathogenesis-related proteins (b-proteins) in immunized tobacco. Phytopathology (USA), 79.

Vitti, A. J. (2009). Soybean seed treatment with abamectin, thiabendazole and acibenzolar-S-methyl for nematodes management. Retrieved from http://repositorio.bc.ufg.br/tede/handle/tde/446

Xavier, S. A., Mello, F. E. de, Canteri, M. G., \& Godoy, C. V. (2015). Fotossíntese de folhas de soja infectadas por Corynespora cassiicola e Erysiphe diffusa. Summa Phytopathologica, 12, 156-159. https://doi.org/ 10.1590/0100-5405/1923

Yánez-Mendizábal, V., \& Falconí, C. E. (2018). Efficacy of Bacillus spp. to biocontrol of anthracnose and enhance plant growth on Andean lupin seeds by lipopeptide production. Biological Control, 122, 67-75. https://doi.org/10.1016/j.biocontrol.2018.04.004

\section{Copyrights}

Copyright for this article is retained by the author(s), with first publication rights granted to the journal.

This is an open-access article distributed under the terms and conditions of the Creative Commons Attribution license (http://creativecommons.org/licenses/by/4.0/). 